\title{
MULTICULTURAL COMPETENCE AND ITS DEVELOPMENT IN STUDENTS OF TEACHER EDUCATION CURRICULA
}

\author{
Anna Džalalova, Nina Raud \\ Narva College of the University of Tartu, Narva, Estonia \\ E-mail: Anna.Dzalalova@ut.ee; Niina.Raud@ut.ee
}

\begin{abstract}
According to the Estonian State Integration Programme the system of education is considered to be one of the main areas of implementing the state integration policy. The main task of schools in Estonia is to support the feeling of belonging for permanent residents of the Estonian society by sharing common values and knowledge of the official language, and to create possibilities for understanding other cultures and establishing methods for cross-cultural communication with various ethnic groups.

The purpose of the research is to study multicultural competence which is considered to be a key component of professional teacher education, as it is of interdisciplinary nature and comprises various aspects which contribute to the development of cognition, personality and professional activities. The research, conducted among students into the level of development of their multicultural competence, has revealed that Narva College students have a positive ethnic identity and quite a high degree of tolerance, which testifies to the positive attitude to their own and other cultures and students' readiness for intercultural communication.

To support the development of multicultural competence in students there has been devised a programme based on such educational components as the comprehensive knowledge of research methods and practices in multicultural education; formation of positive respectful attitude towards native and other cultures; development of skills to support culture-centred education and effective cross-cultural communication; and with inclusion of professional pedagogical activities being based on the humanistic approach and efficient pedagogical interaction.

The research covers key points of how the principles of multilingual and multicultural education are realised in everyday teaching practices to achieve corresponding learning outcomes.

Key words: multicultural competence, multicultural educational environment, principles of multicultural education, teacher education.
\end{abstract}

\section{Introduction}

The issue of multicultural education is very topical in Estonia, which is an ethnically diverse country inhabited by people of more than one hundred nationalities. Before the Second World War Estonia was an ethnically homogeneous society with $80 \%$ of its population being Estonians; at present Estonians represent $68.6 \%$ of the country's population and ethnic minorities and representatives of other nationalities amount to $31.4 \%$ - with Russians as the biggest group of $25.7 \%$, Ukrainians of $2.1 \%$, Byelorussians of $1.2 \%$ and Finns of $0.8 \%$. Collectively there are about 120 different nationalities in Estonia. The Estonian language is mother tongue for $67.2 \%$ of its permanent residents. Other languages and cultures are native for at least one third of the population of Estonia (National minorities and national culture of Estonia, 2012). Therefore the multicultural composition of the school class is rather a norm than an exception for Estonia.

Historically mainstream schools in Estonia are referred to as schools with Estonian or Russian as the language of instruction. In case of Estonian schools with Russian as the language 
PROBLEMS

OF EDUCATION

IN THE $21^{\text {st }}$ CENTURY

Volume 40, 2012

of instruction multiculturalism is a traditional characteristic of their school life organisation.

School students in such schools are Russian speaking children who belong to various cultures, nationalities and religions. In Estonian medium schools Russian speaking children and new immigrants are representatives of other cultures. New immigrants are children from European countries whose parents have moved to Estonia for employment reasons and children from refugees' families.

According to the Estonian State Integration Programme the system of education is considered to be one of the main areas of implementing the state integration policy. The key task of schools in the Republic of Estonia is to make students of all nationalities aware of the priorities and goals of the society's development and of its cultural values; to enrich the individual's perception of other cultures; to reveal and develop ways and forms of intercultural communication between different national and ethnic groups (Estonian State Integration Programme 2008-2013, 2008).

However, according to the outcomes of a survey conducted in 2007 in the European countries by the Eurobarometer service, residents of Estonia are the least interested in crosscultural contacts in comparison with other European countries (Intercultural dialogue in Europe, 2007). The survey showed that Estonia and Hungary are EU member states where for the majority of the population (52\%) the phrase "multicultural dialogue" did not have any particular meaning. In comparison with other residents of the EU, Estonians had fewer contacts with other ethnic and national groups ( $43 \%$ in comparison with the average for the EU of $65 \%$ ). The data also shows that citizens of Estonia communicated with representatives of other religions less than other residents of the EU (18\%). To the question "Can you say that the cultural life of the country is enriched with the help of people who have other cultural backgrounds than the majority of the population?" only $8 \%$ of Estonians answered that it was to the advantage of their lives, which is the lowest percentage in the EU. This situation for a multicultural country is quite alarming. The lack of interest in cross-cultural dialogue could lead to intolerant life positions. However, the earlier the knowledge and skills of how to live in a multicultural society are acquired the easier it might be for an individual to communicate and cooperate with representatives of other cultures and ethnicities. The purpose of the present research is to reveal the degree to which teachers and future student-teachers possess multicultural competence, and to discuss ways of its development in students of teacher education curricula who become kindergarten and school teachers, and who are supposed to become advocates of cross-cultural dialogue, tolerance and empathy.

\section{Theoretical Background}

\section{Principles and Aims of Modern Multicultural Education}

The teacher plays an important role in fostering and developing in her/his students values of mutual understanding, tolerance and readiness for having a dialogue. Tolerance, both as a personality characteristic and as a public position, is a necessary condition for the efficient realisation of the educational process where the teacher's professional practice has to be reconsidered. In order to realise tasks set by the Estonian State Integration Programme for the development of a dialogue of cultures, and for multicultural education, it is necessary to pay special attention to the training of teachers for work in multilingual and multicultural classes, as well as to the formation and development of teachers' multicultural competence (Surveys and Discussions on the Topics of Multiculturalism, Integration and Language Studies in Estonia, 2003).

Modern multicultural education aims at keeping and developing a whole variety and diversity of cultural values, and it is culture-centred in its essence. According to Trasberg (2004) 
multicultural education in the situation of cross-cultural interdependence has to support the preservation and development of self-identity, the formation of cross-cultural communication skills, and it has to prevent and resolve successfully all possible conflicts caused by national or other differences between peoples. Multicultural education empowers every person with a wider range of skills in communication and cooperation with other persons.

Leading specialists in the sphere of multicultural education such as Banks (2004), Gorski (2006), Grant (2007), Nieto (2004), Sleeter (2007) have come to the conclusion that multicultural education has to comply with the following key principles:

- Multicultural education is a political movement and a process by means of which social justice is secured for students who are in disadvantaged/worse conditions;

- Even when principles of multicultural education are implemented in the everyday practices of some educational institutions on a permanent basis, social justice remains an institutional problem as such, and, thus, can be solved only by realisation of a multifaceted school reform;

- The multi-faceted school reform can be carried out only through critical analysis of power structures and privileges;

- The fundamental goal of multicultural education - the aim of this critical analysis - is the elimination of inequality in education;

- Multicultural education means good education for all students.

To sum up, realisation of the key principles of multicultural education presupposes a readjustment of aims and content of education, in accordance with the dynamics of sociocultural values and values of social development.

\section{Today Teacher's Multicultural Competence}

The multicultural educational environment can be characterised in terms of a number of psychological particularities, such as: preservation and development of cultural values and identities in their full diversity, cross-cultural communication, enrichment of the teachingeducational environment with cultural components, a tolerant attitude to representatives of various ethnic communities and cultures, etc. These new demands place new requirements to the professional-pedagogical activities of teachers (Fennes, Hapgood, 1997; Phillion, Ming Fang He, Connelly, 2005; Tiedt, and Tiedt, 2005).

For the efficient fulfillment of pedagogical tasks the modern teacher, on the one hand, has to be aware of multiculturalism in society and education; s/he has to have such psychological characteristics as tolerance and positive ethnic identity, with a well developed system of humanistic values; on the other hand, s/he has to know how to realise the main principles of the multicultural educational process, and how to develop in young persons skills and abilities of adaptation to life in multicultural communities.

The presence and necessity of multicultural competence in teacher education was emphasised by Hutmacher (1997:17). Multicultural competence is a key competence of professional pedagogical competence and, being a complex phenomenon, it includes humanistic values, positive ethnic self-identity and tolerance, knowledge of cultures and their interconnection, mastery of skills and methods applicable for a multicultural educational environment. Thus, multicultural competence is a pre-condition for successful pedagogical and interpersonal communication of the teacher along with other subjects of the educational process. Analysis of various aspects of multicultural competence in works by Pope-Davis, Coleman, Ming Liu, Toporek (2003), Zeichner (1993), Byram, Nichols, Stevens (2001), Banks, McGee Banks $(2004 ; 2008)$ allows one to describe it as a complex phenomenon of interdisciplinary nature, which includes three main components: cultural awareness and cognition, personality's value priority and motivation-based activities (Table 1). 
PROBLEMS

OF EDUCATION

IN THE $21^{\text {st }}$ CENTURY

Volume 40, 2012

Table 1. Teacher's multicultural competence and its components (Džalalova, 2009).

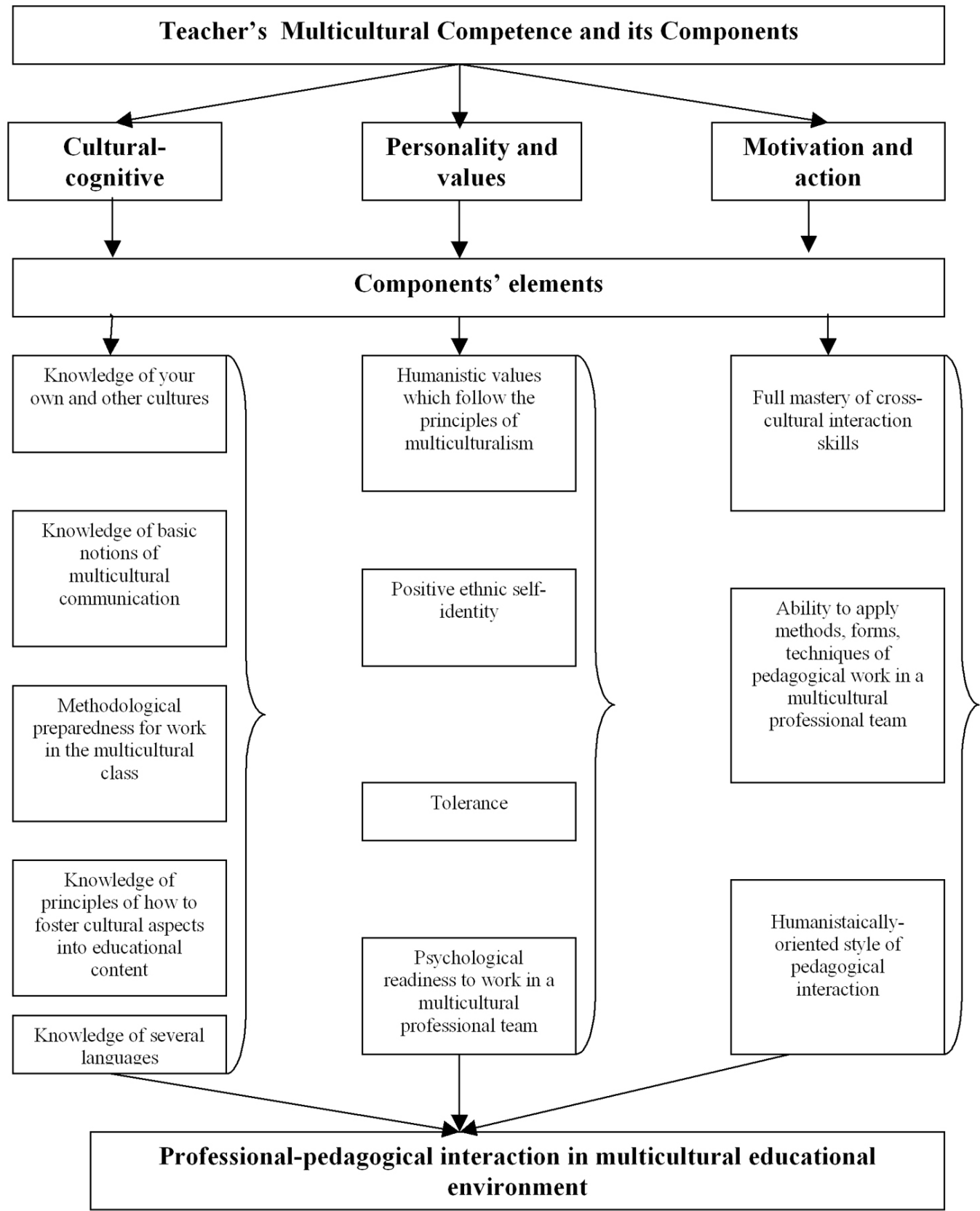

The cultural-cognitive component of teacher's multicultural competence is characterised by the presence of a structured knowledge of teacher's own culture, and of other people's cultures presented in a certain socio-educational environment; it also includes the knowledge of other world cultures and the perception of the world as a multicultural world community; the component includes basic knowledge of multicultural communication and presupposes methodological preparedness for working in the multicultural class as well as knowledge of how to foster cultural aspects into educational content.

The personality and values component includes a well-developed system of humanistic 
values and axiological priorities which follow the principles of multiculturalism; a welldeveloped system of universal and professional values; positive self-identity; tolerance and psychological readiness to work in a multicultural professional team.

The motivation and activity component presupposes mastery of cross-cultural interaction skills; it demonstrates the ability to apply methods, forms, and techniques of pedagogical work in a multicultural professional team; it includes skills in supporting educational processes with cultural aspects; it is realised in the humanistically-oriented style of pedagogic interaction.

\section{Methodology of Research}

Narva College of the University of Tartu has been preparing teachers for Russian medium and multilingual schools and kindergartens since 1999 in the following specialities: "Early Years Teacher", "Primary School Teacher", and "Teacher of Humanities". One of the main priorities of the College in its teacher training activities is the formation and development of multicultural competence in its future student-teachers.

The authors of the present article conducted an empirical research with the purpose to reveal degrees of development of multicultural competence in practicing teachers and students of pedagogical specialities and to define optimal conditions for the support of this competence in teachers and students of higher educational institutions (HEIs).

The sample of the research consisted of 104 Russian speaking teachers of NorthernEastern Estonia and 55 students of Narva College of the University of Tartu.

The research revealed the degree of development of the above mentioned components for multicultural competence in teachers and students.

The main research methods to obtain empirical data were a written survey (for the study of cultural-cognitive component of multicultural competence) and testing (the study of the personality and values component of multicultural competence).

The methods of processing and interpretation of the obtained data were those of mathematical statistics: correlative, comparative and cluster analyses; Student's t-test for probability distribution. The research outcomes were processed with the SPSS statistical analysis programme (version 15.0).

\section{Results of Research}

Analysis of the cultural-cognitive component of teacher's multicultural competence allowed one to state that some teachers show insufficient knowledge of various aspects of Russian and Estonian cultures; the degree to which the teachers' skills and knowledge of how to work in a multicultural team are developed is not appropriate; the majority of teachers self-evaluate their skills and abilities of working with a multicultural team as being low or average.

The personality and values component of the multicultural competence of teachers who participated in the research shows that values and value priorities of modern teachers represent a complex and controversial system; the system is characterised by teachers' high demands to themselves, and to other people and society as a whole. However, there is seen a disparity between real and declared values, which is manifested in aspirations for humanistic values, tolerance, education and refusal from any socially active position.

Though, for the majority of the teachers, positive ethnic identity is a leading quality (Table 2) and they believe that the problem of ethnic tension in Estonia is very topical, yet they remain indifferent to identification of their national identity and they even demonstrate ethno-nihilism, ethno-egotism and ethno-fanaticism. Less that one third of the teachers can be characterised with a high degree of tolerance; the average degree is found with the majority 
PROBLEMS

OF EDUCATION

IN THE $21^{\text {st }}$ CENTURY

Volume 40, 2012

of teachers who participated in the research; with one quarter of the teachers the degree of tolerance is at the lowest level.

Table 2. Types of teachers' ethnic identities $(n=104)$.

\begin{tabular}{|l|c|c|c|}
\hline & $\overline{\mathrm{X}}$ & $\mathbf{m}$ & $\boldsymbol{\sigma}$ \\
\hline Norm (positive ethnic identity) & 18.62 & 0.183 & 1.871 \\
\hline Ethnic indifference & 11.31 & 0.334 & 3.411 \\
\hline Ethno-egotism & 3.15 & 0.274 & 2.797 \\
\hline Ethno-nihilism & 2.58 & 0.277 & 2.824 \\
\hline Ethno-fanaticism & 2.42 & 0.251 & 2.564 \\
\hline Ethno-isolationism & 1.46 & 0.212 & 2.163 \\
\hline
\end{tabular}

Correlation analysis of the empirical data has revealed that there is direct interconnection between the components of the values, and the personality component of teacher's multicultural competence (value priorities, tolerance, and types of ethnic identity). In addition to this there is a direct correspondence between components of the values and personality component, and the cultural-cognitive component (teachers' self-evaluation of their skills and knowledge which are necessary for their work with a multinational team, types of national identity, tolerance and axiological priorities).

Cluster analysis of the empirical data has shown that there are three psychological types of teacher, with different degrees to which multicultural competence is developed: type one - teachers with a low degree of multicultural competence who require additional development of its all components; type two - teachers with a comparatively high degree of multicultural competence but who demonstrate ethnical indifference; type three - teachers with a moderate degree of multicultural competence whose pedagogical style is dominated by authoritarianism and dictatorship.

Thus, the empirical research results show an insufficient degree of development of the components of multicultural competence in teachers of the three psychological types described above. The process of teachers' professional maturity begins at the stage of their professional education, hence it can be assumed that multicultural competence has to be supported, and is already being developed during teacher training. To verify this statement a follow-up research study into the presence of the components of multicultural competence and their development in the students of Narva College was conducted with the aim to make a comparative analysis with the data on teachers.

The research that was conducted gave evidence to conclude that statistically significant differences in the degree of development of the multicultural competence components with the teachers and the students can be seen in (Table 3):

1. the cultural-cognitive component: the students evaluate their knowledge of working with a multicultural team lower than the teachers.

2. the values and personality component: the students have lower degrees of tolerance and positive ethnic identity than the teachers. However, the degree of ethno-isolation and ethno-fanaticism is higher with the students than with the teachers but the degree of ethnic indifference is lower.

To conclude, the degree of tolerance, positive ethnic identity and self-evaluation of knowledge about work with a multicultural team is higher with the students than with the teachers. Besides, the students - in comparison with the teachers - have less expressed values which support principles of multicultural education, such as wider outlook, tolerance, educativeness etc. 
Table 3. Comparative analysis of multicultural competence components with teachers and students.

\begin{tabular}{|c|c|c|c|c|c|c|c|}
\hline & \multicolumn{3}{|c|}{$\begin{array}{c}\text { Teachers } \\
\mathrm{N}=104\end{array}$} & \multicolumn{3}{|c|}{$\begin{array}{l}\text { Students } \\
\mathrm{N}=55\end{array}$} & \multirow{2}{*}{$\begin{array}{c}\mathrm{T}- \\
\text { test }\end{array}$} \\
\hline & $\mathrm{X}$ & $\mathrm{m}$ & $\sigma$ & X & $\mathrm{m}$ & $\sigma$ & \\
\hline \multicolumn{8}{|l|}{ Cultural and Cognitive Component } \\
\hline $\begin{array}{l}\text { Self-evaluation of knowledge on work with a } \\
\text { multicultural team }\end{array}$ & 20.27 & 8.21 & 0.81 & 15.24 & 5.90 & 0.71 & $p<0.001$ \\
\hline \multicolumn{8}{|l|}{ Values and Personality Component } \\
\hline \multicolumn{8}{|l|}{ Tolerance } \\
\hline Degree of tolerance & 24.96 & 3.99 & 0.39 & 22.18 & 4.74 & 0.64 & $p<0.001$ \\
\hline \multicolumn{8}{|l|}{ Types of ethnic identities } \\
\hline Ethnic indifference & 11.29 & 3.44 & 0.34 & 9.64 & 4.09 & 0.55 & $p<0.01$ \\
\hline Positive ethnic identity & 18.62 & 1.87 & 0.18 & 17.71 & 2.19 & 0.30 & $p<0.01$ \\
\hline Ethno-isolationism & 1.44 & 2.20 & 0.22 & 2.91 & 3.31 & 0.45 & $p<0.01$ \\
\hline Ethno-fanaticism & 2.43 & 2.59 & 0.26 & 3.71 & 3.70 & 0.50 & $p<0.05$ \\
\hline \multicolumn{8}{|l|}{ Terminal values } \\
\hline Beauty of nature and the arts & 2.27 & 1.01 & 0.10 & 1.47 & 0.72 & 0.10 & $p<0.001$ \\
\hline Love & 3.79 & 1.07 & 0.11 & 4.38 & 0.89 & 0.12 & $p<0.001$ \\
\hline True and reliable friends & 3.08 & 0.94 & 0.09 & 3.56 & 0.98 & 0.13 & $p<0.01$ \\
\hline Creativity & 3.04 & 1.13 & 0.11 & 1.76 & 0.86 & 0.12 & $p<0.001$ \\
\hline Life wisdom & 3.37 & 1.28 & 0.13 & 2.85 & 1.13 & 0.15 & $p<0.05$ \\
\hline Leisurely life & 1.33 & 0.70 & 0.07 & 1.69 & 0.79 & 0.11 & $p<0.01$ \\
\hline \multicolumn{8}{|l|}{ Instrumental values } \\
\hline Responsibility & 3.37 & 1.01 & 0.10 & 3.93 & 1.14 & 0.15 & $p<0.01$ \\
\hline Strong will & 2.81 & 1.18 & 0.12 & 3.25 & 1.27 & 0.17 & $p<0.05$ \\
\hline Tolerance & 3.77 & 1.02 & 0.10 & 3.16 & 1.24 & 0.17 & $p<0.01$ \\
\hline Wide outlook & 3.58 & 0.99 & 0.10 & 2.89 & 1.12 & 0.15 & $p<0.001$ \\
\hline Educativeness & 4.04 & 0.94 & 0.09 & 3.67 & 1.19 & 0.16 & $p<0.05$ \\
\hline Efficiency & 3.12 & 1.19 & 0.12 & 2.76 & 1.00 & 0.10 & $p<0.05$ \\
\hline
\end{tabular}

\section{Discussion}

Ways of Developing Multicultural Competence in Future Student-Teachers

The research results have shown the necessity for the creation of a programme aimed at preparing students for their work in a multicultural environment, by means of fostering and developing the components of multicultural competence.

To devise the programme, the following principles were taken as guidelines:

1) aim-centredness - this principle is achieved through the realisation of the main goal, i.e. forming and developing multicultural competence in students by means of creating corresponding organisational, didactic and content basics of the educational process;

2) consistency - this principle is realised by means of interdisciplinary links and connection of theory with practice; disciplines are studied in a certain sequence, which is followed-up by application of received knowledge in the area of multicultural education during teaching practice in multicultural institutions; by means of coordinated cooperative work of all participants of the higher educational process;

3) research - students are supposed to acquire knowledge of what multicultural education and cross-cultural communication are at the level of modern scientific research; students are provided with opportunities and support to conduct experimental work and research;

4) awareness and commitment - this principle is realised by means of active methods of teaching and learning; by doing problem-solving and case-study activities relevant to multicultural educational situations; 
PROBLEMS

OF EDUCATION

IN THE $21^{\text {st }}$ CENTURY

volume 40, 2012

5) wholeness - this is achieved by organisation of the educational process as a process of students' personality development, which includes all aspects of their multicultural competence and supports their independent, active, purposeful learning;

6) Cultural appropriateness - this is achieved by conformity to the cultural component of education, by fostering values of world cultures and humanistic values, by instilling tolerant conscience, respect for various cultures, variety and diversity, by applying humanistic technologies in education to solve pedagogic tasks in particular social-cultural situations.

For the successful realisation of the teacher training programme aimed at developing multicultural competence in future student-teachers it is necessary to unite efforts and actions of all participants of the educational process, at both administrative and teaching levels of HEIs. This task might be achieved through the following actions:

1) creation of organisational and methodological conditions to secure the multicultural profile of studies throughout the whole period of students' studies at HEIs;

2) all study processes and activities are interconnected and student-centred; they have to focus on learning by doing and have to follow the principles of multiculturalism;

3) subjects and courses are to be supported by appropriate cultural background; subject matter is considered from the point of cross-cultural interaction; study programmes have to include special subjects on multicultural issues;

4) correspondence and logical interconnection between aims, content, study forms and activities, with learning outcomes aimed at the formation of multicultural competence by means of a humanistic, tolerant, interactive and flexible educational process.

To sum up the above points, the key characteristics of the proposed programme for developing of the students' multicultural competence is the creation of the psychologicalpedagogical environment, the inclusion of multicultural aspects in study programmes, professionalism and readiness of academic staff to teach multicultural aspects and to apply appropriate teaching methods and forms.

Within the context of the programme the following activities are carried out on a regular basis to support the development of multicultural competence in future student- teachers: study trips; research work of students and lecturers on topics of multicultural education; development and teaching of international courses for students from different countries; organisation of teacher-training practice in multicultural institutions; participation of students in traditional scientific conferences on aspects of multicultural education; inclusion into all teacher training programmes such courses as Multicultural education and Cross-cultural communication.

One additional opportunity for the realisation of a multicultural approach to teacher training in HEIs is to include into the disciplines of the Psychological-pedagogical module topics which discuss issues of multiculturalism. With all College's teacher training programmes the course on Basics of Pedagogy considers such topics as "Educational environment of Estonia as a multicultural educational area"; "Aims and tasks of multicultural pedagogy". The course on Methods of Pedagogical Diagnostics includes the topic "Analysis of ethno-psychological characteristics of participants of the educational process". The course on Pedagogical Communication has a section on "Cross-cultural communication". Therefore, the formation of multicultural competence is supported not only by special courses but by including it as a core component into the whole complex of psychological-pedagogical disciplines. This kind of cross-disciplinary connection provides continuity in the formation of multicultural competence in future student-teachers.

One of the main components of multicultural competence is the plurilingualism of future teachers, which is also the core part of teacher training programmes in Narva College. The language policy of the College is focused on developing language competences in three languages, through teaching English/ Estonian for specific purposes, and practicing content and language integrated teaching. All College curricula have language modules which are aimed 
at developing students' language mastery. The volume of subjects varies, with the focus being placed initially on the mastery of Estonian. Second foreign languages such as English, German and French are presented through general language studies, and language courses for specific purposes.

The first outcomes of the realisation of the programme for developing and supporting multicultural competence in students of teacher training programmes of Narva College have already shown that, at the beginning of their studies, students acquire the cultural-cognitive component and the value and personality component of multicultural competence. The control measurements (at the end of the first year of studies) show a decrease in the level of intolerance, and an increase in the degree of students' self-evaluation of their ability to work in a multinational/multicultural team.

\section{Conclusions}

Multiculturalism of contemporary societies demands, from modern education systems and teacher education curricula in particular, new ways and approaches for bringing up an individual who, from her/his early ages, accepts the diversity - both cultural and linguistic - of the community s/he lives in. Kindergartens and schools are the first and the most important places for instilling and developing knowledge and skills of cross-cultural communication. Hence, a teachers' mission is to make this communication possible by their own example, and an ability to understand their own cultures, and place these in the context of the culture and languages present in their community. In view of this fact, the method by which students of any teacher education curricula are prepared for their work in multicultural educational settings is of vital importance.

Teacher education curricula might employ various approaches to develop multicultural competence in their students. The curricula should be based on the key principles of multicultural education which value humanistic values, positive ethnic self-identity and tolerance, knowledge of cultures and their interconnection, mastery of skills and methods applicable to a multicultural educational environment. Structurally, teacher education programmes should not only include topics/courses/modules on multicultural and plurilingual aspects, but should also give students opportunities to apply this knowledge in practice both during their internship and by conducting research activities in the area of multiculturalism and plurilingualism. Close cooperation and support by all participants of the study process is believed to be one of the key aspects of sustainability and continuity of any educators' efforts in multicultural education.

\section{References}

Developing intercultural competence in practice. (2001). / Ed. by Michael Byram, Adam Nichols and David Stevens. Clevedon: Multilingual Matters.

Dzalalova, А. [Джалалова, А. А.]. (2009). Мультикультурная компетентность русскоязычныхх учителей в образовательной среде Эстонии. Диссертаиия на соискание ученой степени кандидата психологических наук. [Multicultural Competence of Russian Speaking Teachers in Estonian Educational Environment. PhD Dissertation] Российский государственный педагогический университет им. А.И.Герцена. Saint-Petersburg.

Fennes, H. (1997). Intercultural Learning in the Classroom: Crossing Borders. / H. Fennes, K. Hapgood. London; Washington: Cassell.

Grant, C.A. (2007). Turning on learning: five approaches for multicultural teaching plans for race, class, gender and disability / Carl A. Grant, Christine E. Sleeter. Hoboken: Wiley.

Gorski, P. C. (2006). Complicity with Conservatism: The De-politicizing of Multicultural and Intercultural Education. Intercultural Education, 17 (2).

Handbook of research on multicultural education. (2004). / Ed. by J. A. Banks, Ch.A. McGee Banks. San Francisco: JOSSEY-BASS. 
PROBLEMS

OF EDUCATION

IN THE $21^{\text {st }}$ CENTURY

Volume 40,2012

Handbook of multicultural competencies in counselling and psychology. (2003) / Ed. by D.B. PopeDavis, H.L.K. Coleman, W. Ming Liu, R.L. Toporek. Thousand Oaks. London. New Delhi: SAGE Publications.

Hutmacher, W. (1997). Key Competencies for Europe // Report of the Symposium. Berne, Switzerland, March 27-30, 1996. A Secondary Education for Europe Project. Retrieved 02/01/2012, from http://www.eric.ed.gov/PDFS/ED407717.pdf

Intercultural dialogue in Europe. (2007). The Gallup Organization. Eurobarometer. Retrieved 25.01.2012. from http://ec.europa.eu/public opinion/flash/fl 217 sum en.pdf.

Narrative and experience in Multicultural education. (2005). / Ed. by J. Phillion, Ming Fang He, E. M. Connelly. Thousand Oaks: Sage.

Nieto, S. (2004). Affirming diversity: the sociopolitical context of multicultural education / S. Nieto. Boston: Pearson Allyn \& Bacon.

Sleeter C. E. (2007). Making choices for multicultural education: five approaches to race, class, and gender / C.E. Sleeter, C.A. Grant. Hoboken: WILEY.

State Integration Programme 2008-2013. (2008). [Unofficial translation]. Tallinn-Tartu. Retrieved 28/05/2011. from http://ec.europa.eu/ewsi/UDRW/images/items/docl_9871_841431476.pdf.

Trasberg, К. (2004). Мультикультурное образование: развитие идей и поиски путей их реализачии в современном мире [Multicultural Education: Ideas Generation and Search for their Realization].// Мультикультурное образование: ключевые вопросы современности и поиск решений [Multicultural Education: Key Issues and Solutions] Ed. L.Vasilchenko. Tartu: [Tartu Ülikool]; [Пылтсамаa]: Vali Press.

Tiedt, P. L. (2005). Multicultural teaching: a handbook of activities, information, and resources / Ed. by P.L. Tiedt, I.M. Tiedt. Boston: Pearson/A\&B.

Zeichner, K. (1993). Educating Teachers for Cultural Diversity. NCRTL Special Report, East Lansing. MI: Michigan State University.

Национальные меньшинства и национальная культура Эстонии. (2010). [National minorities and national culture of Estonia]. Retrieved 25/01/2012. from: http://old.meis.ee/rus/rahvusvahemus.

Обозрение и обсуждения на темы мультикультурности, интеграции и изучения языков в Эстонии. (2003). [Surveys and Discussions on the Topics of Multiculturalism, Integration and Language Studies in Estonia]/ Ed. K. Kallas. Tallinn: Mitte-eestlaste Integratsiooni Sihtasutus.

Advised by Inci Dirim, University of Vienna, Austria

Received: January 23, 2012

Accepted: March 04, 2012

\begin{tabular}{|ll} 
Anna Džalalova & PhD, Lecturer of Psychology and Pedagogy, Head of Division of Psychology and \\
& Pedagogy, Narva College of the University of Tartu, Kerese 14, 20304, Narva, \\
& Estonia. \\
& E-mail: Anna.Dzalalova@ut.ee \\
& Website: http://www.narva.ut.ee \\
\hline Nina Raud & PhD, Lecturer of English, Head of Division of Foreign Languages, Narva College \\
& of the University of Tartu, Kerese 14, 20304, Narva, Estonia. \\
& E-mail: Niina.Raud@ut.ee \\
& Website: http://www.narva.ut.ee
\end{tabular}

